\title{
The smokybrown cockroach: potential new pest in California
}

\author{
A.G. Appel a Michael K. Rust a Donald A. Reierson
}

\begin{abstract}
Infestations of this introduced pest have spread to at least 17 locations in three California counties. Localized control may be possible by surveying for infestations, inspecting cargo vehicles, applying chemicals, and trapping.
\end{abstract}
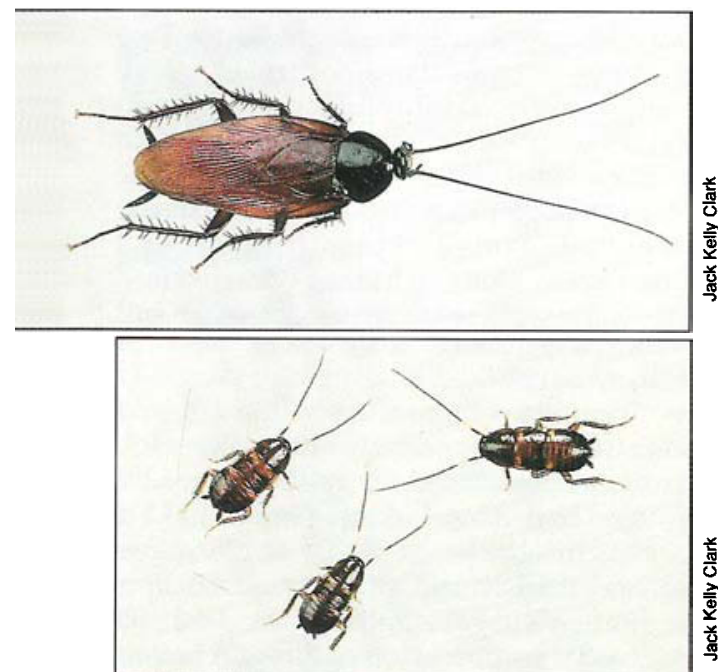

The wings of the adult smokybrown cockroach (top) extend beyond the tip of the abdomen, unlike those of the male oriental cockroach (below, left). Smokybrown nymphs (above) are distinguished by the the light-colored banding absent from oriental nymphs (bottom).
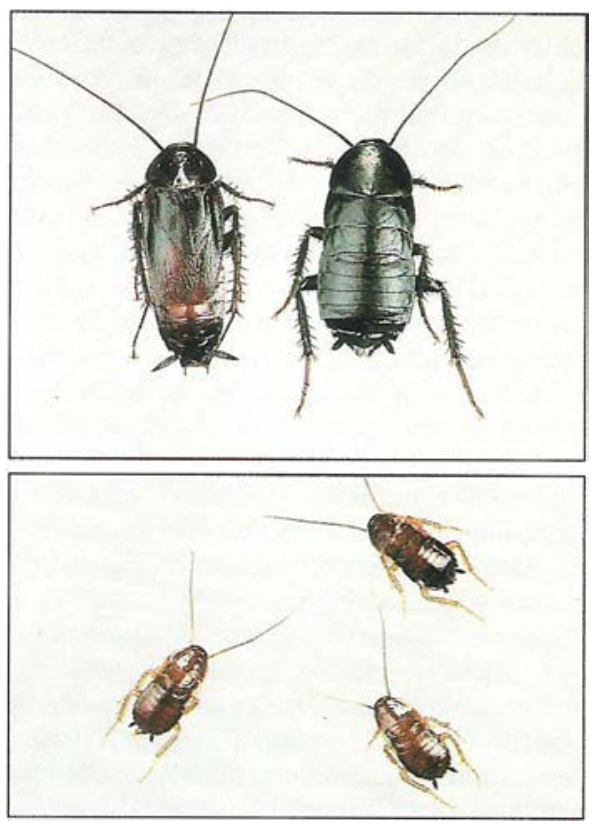

The first California infestation of the smokybrown cockroach, Periplaneta fuliginosa (Serville), was reported in 1972 in the Meadowview area of Sacramento. Since then, at least 17 locations in several cities in Los Angeles, Orange, and Sacramento counties have reported infestations. This cockroach is mainly an outdoor pest in areas throughout the southeastern United States, from central Texas east to Florida and northward to North Carolina. It has been reported as a greenhouse pest in the Midwest, and is a major commercial and structural pest in the orient, especially in China and Japan. The smokybrown cockroach is primarily a subtropical species that is sensitive to desiccation. It can survive well in moderate coastal locations or in relatively dry areas where it can exploit high-humidity manufactured microhabitats, such as water meter boxes and other masonry enclosures, sewer systems, landscaping bark, planter boxes, and woodpiles.

Like the American cockroach, $P$. americana (L.), smokybrown cockroaches readily feed on animal excrement. They have been found in sewers and may serve as mechanical vectors of disease organisms. Although there are no definitive epidemiological studies on the subject, pathogenic bacteria such as Streptococcus spp. and Shigella spp. and protozoa such as Giardia spp. have been isolated from many cockroach species. Several Periplaneta species also serve as intermediate hosts for a variety of nematodes and other worms. Cockroaches are usually considered repugnant and socially unacceptable, particularly large species found indoors.

\section{Description}

As with most insect pests, correct identification of the smokybrown cockroach is important because methods for its control dif语 fer from those used for other common spe产 cies. Smokybrown cockroaches should be eliminated as soon as they are discovered, before they reproduce to very large numbers.

The smokybrown cockroach is a rather large species; adults are 1 to $1 \frac{1}{2}$ inches long ( 25 to $35 \mathrm{~mm}$ ). Cockroaches of similar size include the American cockroach; the brown cockroach, P. brunnea Burmeister; and the . oriental cockroach, Blatta orientalis (L.). American and oriental cockroaches are common throughout California. The brown cockroach is rarely found here; it is mostly restricted to tropical regions like southern Texas and Florida. Both American and brown cockroaches are reddish to dark brown with cream-colored patterns on the pronota, the shieldlike plate that covers the back of the head. The pronota of smokybrowns is uniformly brown, with no pattern. Adult oriental cockroaches are shiny black, with unpatterned pronota, and are therefore often confused with smokybrowns. However, oriental cockroaches have short wings or stubs, and smokybrown cockroaches have long wings that extend beyond the tip of the abdomen.

The young $P$. fuliginosa nymph (the immature, wingless stage) is black, with distinctive white-banded antennae and white stripes on its back. This contrasting color is less pronounced in later instars because they become more brown in overall color. Older smokybrown nymphs are uniformly brownish and look like older, immature oriental cockroaches. However, unlike oriental cockroaches, smokybrowns can easily climb vertical smooth surfaces like porcelain or metal. Young smokybrown cockroach nymphs often stand with their last few abdominal segments held above their body, much like an earwig or scorpion. Blatta and Periplaneta adults are easily distinguished from one another, but their nymphs may need to be sent to an expert for positive identification.

\section{Life history and habits}

The smokybrown cockroach has one to two generations per year. In southern California, populations are much lower during the winter, and any stage can overwinter. In Japan, winters are much colder than in California, and only middle instars can overwinter. Similarly in Texas, the percentage of nymphs in outdoor populations of $P$. fuliginosa is higher from November to February than in the summer months. We have observed outdoor nocturnal activity and feeding by all stages in Orange County, California and in Houston, Texas sites in January, when temperatures were as low as $50^{\circ} \mathrm{F}$ $\left(10^{\circ} \mathrm{C}\right)$.

Adult female smokybrown cockroaches deposit dark-brown egg cases (oothecae) that are 10 to $15 \mathrm{~mm}$ long, each of which contains up to 30 developing young. The oothecae differ considerably from those of P. americana or B. orientalis, which have only about 12 to 15 young each. Females usually place their oothecae in secluded sites with high relative humidities, such as under rocks, in water meter boxes, or in woodpiles. They sometimes place their oothecae in unprotected places like wooden shingles, on bare wood in attics, or on painted stucco and masonry surfaces. They often use their saliva to affix the ootheca to a surface. In laboratory studies, only about $60 \%$ of the oothecae held 2 months at $80^{\circ} \mathrm{F}\left(27^{\circ} \mathrm{C}\right)$ and 
$55 \%$ relative humidity were viable, but more than $87 \%$ of the nymphs that hatched reached maturity.

Like most cockroaches, smokybrown cockroaches are opportunistic feeders. They readily eat scraps of human and pet food, dead earthworms and insects, and animal (bird, cat, and dog) excrement. They will also eat plant materials such as ripe figs ( $F i$ cus spp.), pecan (Carya illinoensis) catkins, and dandelion (Taraxacum spp.) flowers. They drink from standing pools or obtain drinking water from dew, landscape water, and from storm drains, sewers, or gutters. Smokybrown cockroaches have been observed in the early evening foraging for food and water many meters from their home harborages.

\section{Survey and ecology}

In 1984, we surveyed an Orange County residential neighborhood infested with smokybrown cockroaches. In our preliminary survey, we examined water meter boxes at 85 single residences along six parallel and three cross streets. Smokybrown cockroaches were found at 15 residences $(17.7 \%)$ and oriental cockroaches at 23 (27.1\%). A mixed population of the two species was found only once, in a water meter box (1.2\%). All stages of smokybrown cockroach and all except the adult male stages of oriental cockroach were observed. Likely harborages in heavily infested areas included the areas beneath flower pots and planters, sewer shafts, thick patches of ivy groundcover, and woodpiles.

To estimate the movement, population size, and distribution pattern of an established large population of smokybrown cockroaches under field conditions, we conducted a mark-recapture study in Houston. We recaptured adult males $(58.8 \%)$ more often than adult females (34.3\%). Males had significantly larger home ranges ( $280 \mathrm{~m}^{2}$ for males vs. $107 \mathrm{~m}^{2}$ for females). Traps near harborage sites caught more than $70 \%$ nymphs, whereas traps at nonharborage locations caught less than $43 \%$ nymphs. These data indicate that adult male smokybrown cockroaches move significantly greater distances than other stages, but that both males and females may move a long way. Extended home ranges suggest that successful pest management may require a broad, area-wide control pro- gram. Treatment of harborages and removal of food and water sources will aid control.

There have been few studies of the occurrence of smokybrown cockroaches indoors. Although there have been many reports, this species, like the oriental cockroach, appears to be only an incidental indoor intruder in southern California, indicating that preventive indoor pesticide applications of sprays or dusts are probably unnecessary.

\section{Control}

Because of its scattered distribution, large home range, and varied habits, eradication of the smokybrown cockroach may not be feasible in California. Localized control may be possible if the limits of infestation can be identified by an intensive survey and if appropriate treatments are made. The pest's long-range foraging activity may cause reinfestation, particularly during very dry weather or adult flights. Interstate movement of infested vehicles or cargo may also support introductions and reinfestations. We have seen hatched smokybrown oothecae and other evidence of cockroaches on travel trailers from Texas that had parked in newly infested areas of southern California. Oothecae are the most frequently encountered stage because they may be deposited nearly anywhere on a vehicle or in its contents. Vehicle inspection at the point of origin, at stations on state borders, and at the destination might help reduce the movement of infested vehicles from the southeast, particularly from eastern Texas.

Little research has been conducted on the control or management of smokybrown cockroaches. Two parasitic wasp species have been identified in Texas, but out of over 200 oothecae we have collected in California, we have found no instances of parasitization. Introduction of these parasites to California might aid in the control of $P$. fuliginosa.

Preventive measures such as caulking cracks leading into the home, using tightfitting screens and screen doors, removing vegetation and mulch from around the foundation and sides of the home, and removing woodpiles and debris would help by eliminating harborage sites and entry points into structures. Preventive

\begin{tabular}{|lccc|}
\hline \multicolumn{4}{|c|}{ Table 1. The performance of baits and perimeter sprays against smokybrown cockroaches, } \\
Periplaneta fuliginosa
\end{tabular}

treatments in attics with dusts like Dri-Die or Drione would also repel smokybrown cockroaches and eliminate those places as potential harborages. Discrete bait stations containing dilute toxic food bait, used as directed on the label for controlling American or oriental cockroaches, will probably control the few smokybrown cockroaches that happen to gain entry. Cockroaches found in sewers can be controlled by power dusting with Drione or boric acid.

The use of scattered Baygon $2 \%$ bait insecticide and perimeter sprays with Knox Out 2FM microencapsulated diazinon to control smokybrown cockroaches was evaluated at a condominium complex in Irvine, California. Tenants complained of cockroaches in garages, around and on patios, and occasionally inside the home. Two commercially available cockroach sticky traps were placed in the front yards and two in the backyards of each condominium to ascertain the incidence of cockroaches. The traps were placed along fences, walls, next to potted plants and planter boxes, and other areas likely to harbor cockroaches. The traps were retrieved after 1 week and returned to the laboratory where their contents were counted.

The units were randomly divided into four treatments and an untreated control. Treatments included the application of $2 \%$ Baygon bait at a rate equivalent to $113.4 \mathrm{~g}$ per $92.9 \mathrm{~m}^{2}$ ( $4 \mathrm{oz}$ per $\left.1,000 \mathrm{ft}^{2}\right)$ and $226.8 \mathrm{~g}$ per $92.9 \mathrm{~m}^{2} ; 0.5 \%$ Knox Out sprays at 379 liter per $92.9 \mathrm{~m}^{2}$ (10 gal of finish spray per 1,000 $\left.\mathrm{ft}^{2}\right)$; and a combination of Baygon bait at $113.4 \mathrm{~g}$ per $92.9 \mathrm{~m}^{2}$ and $0.5 \% \mathrm{Knox}$ Out sprays at 37.9 liter per $92.9 \mathrm{~m}^{2}$.

The outdoor areas were trapped 3 and 6 weeks after treatment, and we compared the difference between the initial and final trap counts with a Wilcoxon's signed-rank test. Applications of the 2\% Baygon bait at twice the registered rate $\left(113.4 \mathrm{~g}\right.$ per $\left.92.9 \mathrm{~m}^{2}\right)$ failed to reduce the number of smokybrown cockroaches (table 1). Even though it is very toxic on contact to cockroaches, $113.4 \mathrm{~g}$ of bait per $92.9 \mathrm{~m}^{2}$ only provides a deposit of one granule every $6.45 \mathrm{~cm}^{2}$. Clearly, not enough bait was provided per unit area to ensure that cockroaches would contact the bait. Similarly, applications of perimeter sprays or baits plus sprays failed to reduce trap counts at either 3 or 6 weeks after treatment.

Conventional treatment strategies had little effect on this increasingly important pest. Research on its biology and control is continuing in California and at Auburn University in Alabama.

A. G. Appel is Assistant Professor, Department of Entomology, Auburn University; and Michael K. Rust is Professor and Donald A. Reierson is Staff Research Associate, Department of Entomology, UC Riverside. 